\title{
A Proposal for the Transfer of Halorubrobacterium distributum and Halorubrobacterium coriense to the Genus Halorubrum as Halorubrum distributum comb. nov. and Halorubrum coriense comb. nov., Respectively
}

\author{
A. OREN ${ }^{1 *}$ AND A. VENTOSA ${ }^{2}$ \\ The Alexander Silberman Institute of Life Sciences and The Moshe Shilo Center for Marine Biogeochemistry, The Hebrew \\ University of Jerusalem, 91904 Jerusalem, Israel, ${ }^{1}$ and Departamento de Microbiologia y Parasitologia, \\ Facultad de Farmacia, Universidad de Sevilla, 41012 Seville, Spain ${ }^{2}$
}

As the genus Halorubrum was validated before the genus Halorubrobacterium, we propose that the species Halorubrobacterium distributum and Halorubrobacterium coriense should be reclassified as Halorubrum distributum comb. nov. and Halorubrum coriense comb. nov., respectively.

At its open meeting on 4 July 1994 in Prague, Czech Republic, the International Committee on Systematic Bacteriology Subcommittee on the Taxonomy of Halobacteriaceae discussed the taxonomic position of several species that were previously classified in the genus Halobacterium but were sufficiently different from Halobacterium salinarum, the type species of the genus, to warrant classification in a separate genus (7). These species included Halobacterium saccharovorum, Halobacterium trapanicum, Halobacterium sodomense, and Halobacterium lacusprofundi.

A new genus, the genus Halorubrum, comprising the new combinations Halorubrum saccharovorum (type species), Halorubrum sodomense, Halorubrum trapanicum, and Halorubrum lacusprofundi, was proposed by McGenity and Grant (6), and the new names were validly published in January 1996 (1). Independently, Kamekura and Dyall-Smith proposed the genus Halorubrobacterium to include Halorubrobacterium saccharovorum comb. nov. (type species), Halorubrobacterium sodomense comb. nov., Halorubrobacterium lacusprofundi comb. nov., Halorubrobacterium distributum comb. nov., and Halorubrobacterium coriense sp. nov. (3). The new genus name and new combinations were validated in April 1996 (2).

According to Rule 51b of the International Code of Nomenclature of Bacteria (5), the name Halorubrobacterium is a later synonym of the name Halorubrum and as such is illegitimate. Accordingly, Halorubrobacterium coriense sp. nov. and Halorubrobacterium distributum (Kostrikina et al. 1990) (4) comb. nov. (basonym, Halobacterium distributum) should be classified in the genus Halorubrum, which was validated earlier. A footnote to Validation List 57 (2) states that, "Since the new name and the new combinations were already announced in Validation List 56, they have priority over Halorubrobacterium and the corresponding new combinations and therefore they have to be regarded as later synonyms. Consequently, Halorubrobac-

\footnotetext{
* Corresponding author. Mailing address: Division of Microbial and Molecular Ecology, Institute of Life Sciences, The Hebrew University of Jerusalem, 91904 Jerusalem, Israel. Phone: 972-2-6584951. Fax: 972-2-6528008. Electronic mail address: orena@shum.cc.huji.ac.il.
}

terium distributum and Halorubrobacterium coriense should read Halorubrum distributum and Halorubrum coriense, respectively. For reasons of clarity, a taxonomic note would be welcome to solve the problem."

On the basis of their polar lipid patterns (the lipids include a sulfated diglycosyl diether lipid and the diether derivative of phosphatidylglycerosulfate), the nucleotide sequences of their 16S rRNA-encoding genes, and other criteria, Halorubrobacterium distributum and Halorubrobacterium coriense conform with the description of the genus Halorubrum (6). Therefore, we propose the following new combinations: Halorubrum distributum (Kostrikina et al. 1990) comb. nov. (basonyms, Halorubrobacterium distributum and Halobacterium distributum) (type strain, strain VKM B-1733 [= JCM 9100]) and Halorubrum coriense (Kamekura and Dyall-Smith 1995) comb. nov. (basonym, Halorubrobacterium coriense) (type strain, strain ACM 3911).

\section{REFERENCES}

1. International Journal of Systematic Bacteriology. 1996. Validation of the publication of new names and new combinations previously effectively published outside the IJSB. List no. 56. Int. J. Syst. Bacteriol. 46:362-363.

2. International Journal of Systematic Bacteriology. 1996. Validation of the publication of new names and new combinations previously effectively published outside the IJSB. List no. 57. Int. J. Syst. Bacteriol. 46:625-626.

3. Kamekura, M., and M. L. Dyall-Smith. 1995. Taxonomy of the family Halobacteriaceae and description of two new genera Halortbrobacterium and Natrialba. J. Gen. Appl. Microbiol. 41:333-350.

4. Kostrikina, N. A., I. S. Zvyagintseva, and V. I. Duda. 1990. Cytological peculiarities of Halobacterium distributus, an extremely halophilic archaebacterium. Mikrobiologiya 59:70-74.

5. Lapage, S. P., P. H. A. Sneath, E. F. Lessel, V. B. D. Skerman, H. P. R. Seeliger, and W. A. Clark (ed.). 1992. International code of nomenclature of bacteria. 1990 revision. American Society for Microbiology, Washington, D.C.

6. MeGenity, T. J., and W. D. Grant. 1995. Transfer of Halobacterium saccharovorum, Halobacterium sodomense, Halobacterium trapanicum NRC 34041, and Halobacterium lacusprofundi to the genus Halorubrum gen. nov., as Halorubrum saccharovorum comb. nov., Halorubrum sodomense comb. nov., Halorubrum trapanicum comb. nov., and Halorubrum lacusprofundi comb. nov. Syst. Appl. Microbiol. 18:237-243.

7. Oren, A., and A. Ventosa. 1996. International Committee on Systematic Bac teriology Subcommittee on the Taxonomy of Halobacteriaceae. Minutes of the meeting, 4 July 1994, Prague, Czech Republic. Int. J. Syst. Bacteriol. 46:361. 